Agro-Science Journal of Tropical Agriculture, Food, Environment and Extension Volume 8 Number 3 September 2009 pp. 139 - 144

ISSN1119-7455

\title{
THE IMPACT OF THE NATIONAL FADAMA II DEVELOPMENT PROJECT IN ALLEVIATING RURAL POVERTY AND IMPROVING AGRICULTURAL PRODUCTION IN IMO STATE, NIGERIA
}

\author{
Ezeh C. I. \\ Department of Agricultural Economics and Extension Abia State University, Umuahia \\ Campus Umuahia, Abia State, Nigeria
}

\begin{abstract}
This study determined the impact of the National Fadama II development project in alleviating rural poverty and agricultural production in Imo State, Nigeria. All the three (Okigwe, Orlu and Owerri) agricultural zones were involved in the study. A multi-stage random sampling technique was used to select 240 (120 apiece for Fadama II and non Fadama II farmers) respondents from which inputoutput data were collected. Instrument for data collection was a set of structured and pre-tested questionnaire. The poverty line was N12,925.24 and N7,908.42 per month for Fadama II and non Fadama II farmers, respectively. Poverty incidence was 0.5367 and 0.3215 for Fadama II and non Fadama II farmers, respectively while the poverty gap was 0.0337 and 0.1113 for Fadama II and non Fadama II farmers, respectively. The result of the paired $t$-test showed that the national Fadama II development project impacted positively and significantly on beneficiaries' output, income and labour use level at 5.0\% risk level of significance. It was recommended that farmers should be given increased access to Fadama lands to help boost agricultural output and reduce endemic poverty.
\end{abstract}

Key words: Impact, National Fadama II Facility, Poverty Alleviation, Agricultural Production

\section{INTRODUCTION}

In Nigeria, poverty and its excruciating impact are pervasive and palpable on the people, especially the rural dwellers. With the projections made by the World Bank that poverty in Nigeria will increase by two-thirds, with the possibility of $60 \%$ of the population living below the poverty line in ten years, the government of Nigeria adopted the concept of poverty alleviation as a major thrust of its annual budget since 1996 (Amalu, 2005). In order to raise the standard of living of the people and instil in the poor people some sense of belonging, several Nigerian governments have adopted and implemented various poverty alleviation programmes. One of such programmes is the National Fadama Development Project.

Imo State was among the 12 World Bank assisted states implementing the second National Fadama II Development Project, which aimed at sustainably increasing the income of all users of fadama resources and to reduce conflict among fadama user groups (Imo State Fadama Development, 2000). It is believed that the provision of this development project should not only boost agricultural production but enhance the income of the farmers and thereby lift them out of the vicious cycle of poverty (Ayanwale and Alimi, 2004).

For the success of any poverty alleviation programme, however, knowledge of the profile of poverty in that society is essential. Studies have shown that agriculture is the dominant occupation of the poor rural dwellers in Nigeria (World Bank, 1996). Agriculture remains the mainstay of Nigerian economy, contributing about $40 \%$ of the total GPD, and employing about $77 \%$ of the working population (Ayanwale and Alimi, 2004). It thus became imperative that appropriate policy measures aimed at alleviating poverty must take agriculture into consideration. Studies have shown that poor families are in higher proportion in farming households who are mainly in the rural areas. Regions where agriculture is the major source of employment has the higher incidence of poverty (Khan, 2000; CBN/World Bank, 1996). 
An obvious way of reducing poverty is enabling the farming poor to increase their agricultural output, so as not only to improve their incomes but to lift them above the level of subsistence. This widening gap between Nigeria's food production and consumption requires tremendously increased gain in agricultural productivity. This is what the Fadama II development project is set out to achieve. If the Fadama II development project achieved the envisaged objectives, the welfare of rural households would be improved with the attendant multiplier effect on the community as a whole.

The specific objectives of this study include the following:

i. describe the socio-economic characteristics of the beneficiary and non beneficiary farmers in Imo State;

ii. determine the poverty line, poverty incidence and poverty gap between the Fadama II and non Fadama II farmers; and

iii. determine the effect of the programme on participants farm income, output and farm size.

\section{MATERIALS AND METHODS}

The study area was Imo State. The State was purposively chosen because it was the only State in the south-eastern political zone of Nigeria to benefit from the National Fadama II development project. The state lies between $5^{\circ} 10^{\prime}$ and $6^{\circ} 35^{\prime}$ 'north of the equator as well as between longitude $6^{\circ} 35^{\prime}$ and $7^{\circ} 35^{\prime}$ east of the Greenwich meridian.(NAERLS, 1995). All the three agricultural zones (Orlu, Okigwe, and Owerri) were involved in the study. Multi-state random sampling technique was used in the selection of samples. First, One Local Government Area was selected at random from each agricultural zone. The selected LGAs were Onuimo (Okigwe zone); Abo Mbaise (Owerri zone) and Oguta (Orlu zone). Second, four fadama practicing villages were selected from each LGA thus giving a total of 12 villages. Third, 10 Fadama II participating farmers were randomly selected from each community, thus giving a subsample size of 120 respondents. To provide for the non-fadama II participating farmers, another set of 120 farmers were randomly selected bringing the total sample size to 240 . Data for the study were collected using cost route technique, which is simply described as the collecting of data at the time the farmer is performing each operation. It also involved the use of two sets of structured and pretested questionnaires administered on the two selected groups of farmers. The crops involved in this study were maize, upland rice, garden egg fruits, telfeiria leaves, okro fruits and Amaranthus fruits. These crops were weighed in the company of the farmers and the weights recorded in kilogrammes.

Mean and frequency count were used to achieve objective one; poverty parameters were used to analyze and draw inference on objective two while paired t-test was used to realize objective three.

In estimating the extent of poverty among the two groups of farmers, the following equations were used according to Ayobatele and Amudipe (1999) and Ezeh (2007):

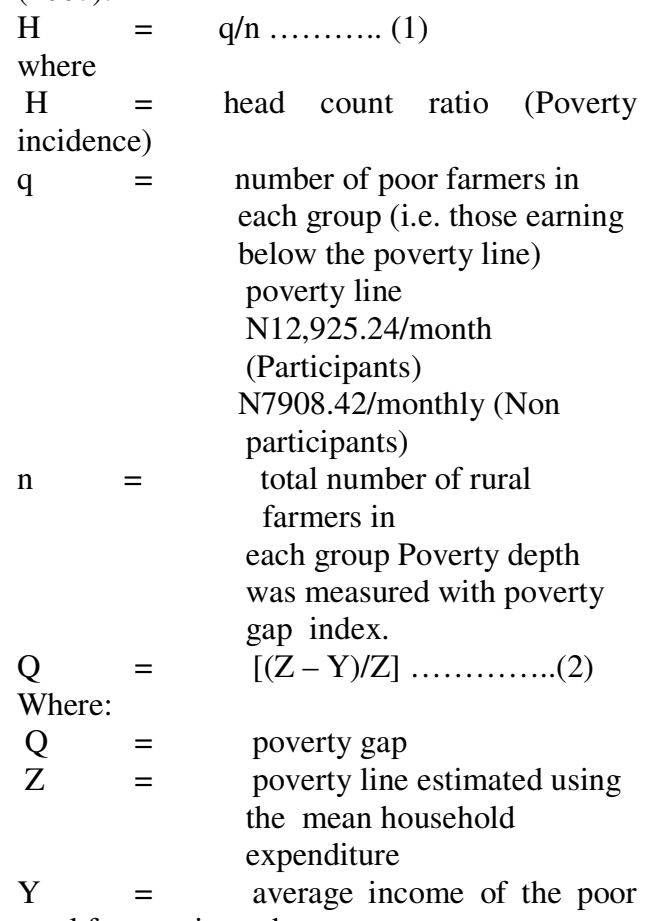

rural farmers in each group

NB: Poverty line $=$ mean household expenditure Paired treatment test (paired " $\mathrm{t}$ " test) was used according to Nwachukwu and Ezeh (2007 as follows:

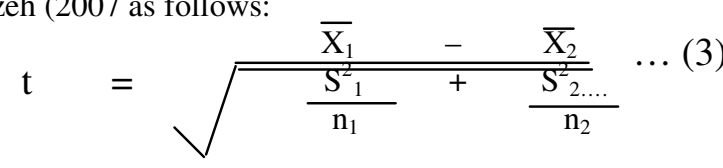

$\mathrm{n}_{1}+\mathrm{n}_{2}$ degree of Freedom

where

$\begin{array}{lll}\mathrm{t} & = & \text { paired } \mathrm{t} \text { statistic } \\ \mathrm{X}_{1} & = & \begin{array}{l}\text { mean parameters of Fadama } \\ \text { participants }\end{array}\end{array}$ 


$\begin{array}{lll}\overline{\mathrm{X}_{2}} & = & \begin{array}{l}\text { mean parameters of non } \\ \text { Fadama II participants } \\ \text { Variance of parameters of }\end{array} \\ \mathrm{S}_{1}{ }_{1} & = & \begin{array}{l}\text { Fadama II participants } \\ \text { Variance of parameters of }\end{array} \\ \mathrm{S}_{2}{ }_{2} & = & \begin{array}{l}\text { Fadama II participants } \\ \text { number of selected Fadama } \\ \text { non }\end{array} \\ \mathrm{n}_{1} & = & \begin{array}{l}\text { farmer participants } \\ \text { II }\end{array} \\ \mathrm{n}_{2} & = & \text { Fadamber of selected no }\end{array}$

Hypothesis tested

Ho: There is no significant difference on effects between the income level, output level, farm size and fertilizer use level of Fadama II and non Fadama II farmer participants.

\section{RESULTS AND DISCUSSION}

The mean values of some socioeconomic variables are shown in Table I. The table shows that the mean age of Fadama II participating farmers was 44.2 years while that of the non participating farmers was 45.05 years. The results indicated that both groups of farmers were within the middle-aged group which was still energetic and productive. The implication is that this group of the respondents comprise rational decision makers and time is still at their disposal to establish indelible reputation within the community (Onyenucheya and Ukoha, 2007; Akpa, 2007).

Table 1: Mean values of some socioeconomic characteristics of the farmers participants in Fadama II and Non Fadama II farmers in Imo State, Nigeria

\begin{tabular}{lll}
\hline $\begin{array}{l}\text { Socio-economic } \\
\text { variables }\end{array}$ & $\begin{array}{l}\text { Fadama II } \\
\text { Farmer } \\
\text { Participants }\end{array}$ & $\begin{array}{c}\text { Non Fadama } \\
\text { II Farmers }\end{array}$ \\
\hline $\begin{array}{l}\text { Age of farmers (years) } \\
\text { No. of years in }\end{array}$ & $\begin{array}{l}\text { II.22 } \\
\text { Education (years) }\end{array}$ & 45.05 \\
$\begin{array}{l}\text { Farming experience } \\
\text { (years) }\end{array}$ & 14 & 08.49 \\
$\begin{array}{l}\text { Farm size (ha) } \\
\text { Household size }\end{array}$ & 0.86 & 11 \\
$\begin{array}{l}\text { Monthly farm income } \\
\text { (N) }\end{array}$ & 6.0 & 0.84 \\
$\begin{array}{l}\text { Output (kg) } \\
\text { Labour use } \\
\text { (mandays) }\end{array}$ & 7336.15 & 6.0 \\
\hline Source: Field Survey data, 2007 & 7027.82 \\
& 70.04 & 5427.97 \\
\hline
\end{tabular}

The mean values of the number of years spent in school (Table 1) shows that Fadama II farmer participants spent 12.71 years in school while the non fadama II farmer participants spent a mean of 8.44 years in school. The results show that literate farmers in both categories of farmers grossly dominate the study area. This result is consistent with Obasi
(1991) that opined that the level of education attained by a farmer not only increases his farm productivity but also enhances ability to understand and evaluate new production technologies. The ability to read and write would enable both groups of farmers to better utilize effectively and efficiently whatever resources that are available in the area (Ezeh, 2007).

Table 1 also indicates that the respondents involved in Fadama II farming had mean farming experiences of 14 years as against 11 years for non participants. The results reveal that both groups of farmers had reasonable wealth of years of farming experience. Experience has been shown to enhance more efficient use of scarce resources by smallholders in Nigeria (Ezeh, 2007).

Table 2: Distribution of the respondents according to monthly expenditure in Imo State Nigeria

\begin{tabular}{lcccc}
\hline & \multicolumn{2}{c}{$\begin{array}{c}\text { Fadama II Farmer } \\
\text { Participants }\end{array}$} & \multicolumn{2}{c}{$\begin{array}{c}\text { Non-Fadama II Farmer } \\
\text { Participants }\end{array}$} \\
\cline { 2 - 5 } $\begin{array}{l}\text { Expenditure } \\
\text { Groups }\end{array}$ & Frequency & Percent & \multicolumn{1}{c}{ Frequenc } & Percent \\
\hline $1000-10,000$ & 62 & 51.67 & 98 & 81.67 \\
$10,001-20,000$ & 36 & 30.00 & 14 & 11.67 \\
$20,001-30,000$ & 12 & 10.00 & 8 & 06.61 \\
$30,001-40,000$ & 8 & 6.67 & - & - \\
$40,001-50,000$ & 2 & 1.66 & - & - \\
Above 50,000.00 & - & - & - & - \\
Total & 120 & 100.00 & 120 & 100.00 \\
\hline
\end{tabular}

Source: Field Survey data, 2007

Table 3: Poverty Indicators of the Fadama II farmers participants and non Fadama II Farmer in Imo State Nigeria

\begin{tabular}{lll}
\hline Poverty Indicators & $\begin{array}{l}\text { Fadama II } \\
\text { Farmer } \\
\text { Participants }\end{array}$ & $\begin{array}{l}\text { Non Fadama II } \\
\text { Farmers }\end{array}$ \\
\hline $\begin{array}{l}\text { Poverty line (monthly } \\
\begin{array}{l}\text { Expend.) } \\
\text { Head count ratio } \\
\text { (poverty incidence) }\end{array}\end{array}$ & $\begin{array}{l}\text { (monthly) } \\
0.5367\end{array}$ & N7908.42 (monthly) \\
$\begin{array}{l}\text { Poverty gap (poverty } \\
\text { depth) }\end{array}$ & 0.0337 & 0.32155 \\
\hline
\end{tabular}

Source: Field survey data, 2007

The mean size of farmland cultivated by the households was 0.86 ha for Fadama II participants and 0.84 ha for non participants. This result is consistent with Awoyemi (1999) who reported that farmers in Nigeria are predominantly smallholders with average farm size of between 1 and 2 hectares. He postulated that it is even smaller in the eastern states where population pressure is more acute. He cited the case of Abia State where average farm sizes of 0.2 ha for both male and female farmers had been recorded. Since the units of 
Table 4: Results of the paired t-test for mean and mean difference in farm output, farm income, farm size and labour use level of Fadama II and non Fadama II farmers in Imo State, Nigeria

\begin{tabular}{|c|c|c|c|c|c|}
\hline \multirow[t]{2}{*}{ Paired categories } & \multicolumn{5}{|c|}{ Paired Differences } \\
\hline & Mean & Mean difference & Standard deviation & Standard error of mean & t-value \\
\hline \multicolumn{6}{|l|}{ Pair 1} \\
\hline $\mathrm{X}_{1}$ & 7538.6333 & & & & \\
\hline $\mathrm{X}_{2}$ & 5427.9668 & & & & \\
\hline $\mathrm{X}_{1}-\mathrm{X}_{2}$ & & 2110.6667 & 10720.9148 & 978.811 & $2.157 * *$ \\
\hline \multicolumn{6}{|l|}{ Pair 2} \\
\hline $\mathrm{X}_{3}$ & 13361.15 & & & & \\
\hline $\mathrm{X}_{4}$ & 7027.82 & & & & \\
\hline$X_{3}-X_{4}$ & & 6333.33 & 77335.5757 & 7059.7399 & $6.112 * * *$ \\
\hline \multicolumn{6}{|l|}{ Pair 3} \\
\hline $\mathrm{X}_{5}$ & 0.86 & & & & \\
\hline $\mathrm{X}_{6}$ & 0.84 & & & & \\
\hline $\mathrm{X}_{5}-\mathrm{X}_{6}$ & & 0.02 & 1.3881 & 0.1267 & -1.559 \\
\hline Pair 4x & 70.0417 & & & & \\
\hline $\mathrm{X}_{8}$ & 32.3583 & & & & \\
\hline $\mathrm{X}_{7}-\mathrm{X}_{8}$ & & 37.6833 & 57.2438 & $5 / 2256$ & $7.211 * * *$ \\
\hline \multicolumn{6}{|c|}{ Source: Computed from Field survey, 2007} \\
\hline Note & $\begin{array}{c}\text { indicates variable is } \mathrm{s} \\
*_{*} \\
\text { indicates } \mathrm{v}\end{array}$ & $\begin{array}{l}\text { ignificant at } 1 \% \\
\text { atistically signific }\end{array}$ & $5 \%$ & & \\
\hline $\mathrm{X}_{1}$ & Mean output $\mathrm{kg}$ ) of $\mathrm{F}$ & mers & & & \\
\hline $\mathrm{X}_{2}$ & Mean output $(\mathrm{kg})$ of $n$ & II farmers & & & \\
\hline $\mathrm{X}_{3}$ & Mean farm income $(\mathrm{N}$ & armers & & & \\
\hline $\mathrm{X}_{4}$ & Mean farm income $(\mathrm{N}$ & 1-fadama II farmer & & & \\
\hline $\mathrm{X}_{5}$ & Mean farm size (hect: & ma II farmers & & & \\
\hline $\mathrm{X}_{6}$ & Mean labour use (Ma & I of fadama II farm & & & \\
\hline $\mathrm{X}_{7}$ & Mean labour use (mar & of non-fadama II & ers. & & \\
\hline
\end{tabular}

production are still small scale, farmers are not in position to take advantage of modern agricultural techniques.

Household size of both groups of farmers was 6 (Table 1). This has major implication in the provision of labour for farm work (Akpa, 2007). The present economic crisis and deepening poverty levels have forced rural households especially women headed households to embark on family planning measures to reduce their number of children. It has been shown that in the past, farmers had married many wives and had large household sizes to be able to provide enough labour for agricultural production. This had been responsible for the high rate of malnutrition, mortality, illiteracy, unemployment especially in the rural economy hence leading to a change in family emphasis (Nnanyelugo, 1980; Ryan et al., 1986, Olusanya, 1980; Okorji, 1999; and Ezeh, 2007).

The mean farm income for Fadama II participants was $\$ 160,333.53$ while that of the non participants was $\$ 84,33.83$. Although these amounts are significant for the average farmer (Ezeh, 2003), Okorji (1999) and Ezeh (2007) classified all mean incomes below $\$ 50,000.00$ as belonging to low income group. The relatively low farm income status of the rural non Fadama II farmers has crippling implication on household welfare, farm production and productivity.
Output levels for Fadama II farmers had a mean of $7538.63 \mathrm{~kg}$ of farm output while the non-participants had a mean output of 5427.97 $\mathrm{kg}$. Output per hectare cannot be maximized with the low yielding, disease prone local varieties.

A majority $(51.67 \%$ of the Fadama II farmer participants and $81.67 \%$ of the non participants) of both respondents spent between $\$ 1000.00$ and $\$ 10,000.00$ per month (Table 2). The significantly low proportion of household expenditure suggests the vicious cycle of poverty often engulfing most rural households in Nigeria. Low expenditure and by extension, low investment in agriculture results in low output with increasing land area the land (Ezeh, 2007).

The poverty indicators of Fadama II participants and non-participants are shown in Table 3. The mean monthly household expenditure (poverty line) of the Fadama II farmers and non Fadama II farmers were estimated to be $\$ 12,925.24$ and $\$ 7,908.42$, respectively. These translate to $\$ 155,102.88$ and $\$ 94,901.04$ per annum, respectively.

These values (mean household expenditures) were used as the poverty line (Ayobatele and Amudipe, 1999).The incidence of poverty otherwise called the head count ratio shows that the value for Fadama II participants was 0.5367 while that of nonparticipants was 0.3215 . This implies that $53.67 \%$ and $32.15 \%$ of the Fadama II and nonparticipants, respectively are poor because 
their incomes fell short of the mean household expenditure used as poverty line.

The poverty gap (poverty depth), or as the income short fall allows for the assessment of the depth of poverty among Fadama II and non-fadama participants. The poverty gap for the Fadama II farmers was 0.0337 while that of the non Fadama II farmers was 0.1113. This implies that the poor Fadama II farmers require $03.37 \%$ of the poverty line to get out of poverty while the poor non Fadama II farmers require $11.13 \%$ of poverty line to get out of poverty. This amounts to N435.58 per poor Fadama II farmer per month or $\$ 5,2226.97$ per annum. This amounts to $\$ 889.21$ per poor non Fadama II farmer per month or $\$ 10,562.49$ per annum.

The result on the paired t-test for differences in farm output, farm income, farm sizes and labour use level between the fadama II participants and non-participants is shown in Table 4. The mean output of Fadama II farmers (pair I) was $7538.6333 \mathrm{~kg}$ while that of the non Fadama II farmers was $5427.9667 \mathrm{~kg}$. The mean difference was $2110.6667 \mathrm{~kg}$. This was statistically significant at $5 \%$ level This means that the null hypothesis of no significant difference between the farm output of Fadama II and non Fadama II farmers is rejected. This result corroborates Ezeh (2004 and 2007).

The mean value of farm income for Fadama II farmers (pair 2) was $¥ 13,361.15$ while that of the non fadama II farmers was $\$ 7027.82$ and the mean difference was \$6,333.33. The mean difference was 2110.67. This was statistically significant at $5.0 \%$ risk level. This result compared favourably with Amalu (2005) and Nwachukwu and Ezeh (2007).

The mean farm size was 0.86 ha for fadama II farmers and 0.84 ha for non fadama II farmers. The mean difference was 0.02 ha. This was not statistically significant at $5 \%$ levels. Hence the null hypothesis of no difference in farm size between the tow groups of farmers is accepted.

The mean labour use level for the Fadama II farmers was 70.0417 mandays while that of the non Fadama II farmers was 32.3583 mandays. The difference was 37.6833 mandays. This was statistically significant at $5.0 \%$ level of probability hence the null hypothesis of no difference in labour use level of the two groups is rejected. The result is consistent with those of Nwachukwu and Ezeh (2004) and Ezeh (2007).

\section{CONCLUSION AND RECOMMENDATION}

The research had shown that the mean household expenditure of the Fadama II farmers was $\$ 12,925.24$ per month while that of the non Fadama II farmers was 7908.42 . The study also showed that the poverty incidence was 0.5367 for the Fadama II farmers and 0.3215 for the non Fadama II farmers. The poverty gap also known as income shortfall was 0.0337 and 0.1113 for the poor Fadama II and non-participants, respectively. National Fadama II development facility had impacted significantly on farm output, farm income and labour use level of the Fadama II farmers in Imo State, Nigeria.

Based on the findings, the following recommendations were made:

1. The scope of the national Fadama III Facility should be enlarged to accommodate more willing farmers as evidence has shown that Fadama II impacted positively and significantly on some economic indices of the participants.

2. The level of funding by the National Fadama III development project should be increased as evidence has shown that the level of poverty experienced even by the Fadama II farmers was high. Increased funding has the attendant effect of enabling farmers to venture into new fields of agricultural investment and help to realize the much needed food security objectives.

\section{REFERENCES}

Akpa, E. C. (2007). A Comparative Analysis of the Impact and Technical Efficiency of Fadama II and Non Fadama II Arable Crops Farmers in Imo State, Nigeria. B. Agric. Thesis. Dept of Agricultural Economics and Extension, Abia State university Uturu.

Amalu, U. C. (2005) Poverty Alleviation and Agriculture in Sub-Saharan Africa: The Nigerian experience. Journal of Food, Agriculture and Environment, 3(2): $230-235$.

Ayanwale, A. B. and T. Alimi (2004) The Impact of the National Fadama Facility in Alleviating Rural poverty and enhancing agricultural development in South-Western Nigeria. J. Soc. Sci., 9(3): $157-161$.

Ayobatele, J. T. and D. A. Amudipe (1999) Poverty Profile of Working Women in Akure North and South LGAs of Ondo State. In Fabiyi, Y. L. and E. O. Idowu (eds.). Poverty Alleviation and Food Security in Nigeria 
Nigerian Association of Agricultural Economists (NAAE): 127 - 131.

Central Bank of Nigeria/World Bank (1996) Collaborative study on Nigeria's Prospects for Development: Proceedings of a Workshop April 15 $-17$.

Ezeh, C. I. (2003) Credit Worthiness and Determinants of Loan Repayment of Smallholder Farmers in Abia State, Nigeria. Journal of Sustainable Tropical Agricultural Research, 5: 10 $-13$.

Ezeh, C. I. (2004) A Comparative Study of Fadama and non-Fadama Crop Farmers in Osisioma-Ngwa LGA, Abia State, Nigeria. Journal of Tropical and sustainable Agriculture, 13: $31-36$.

Ezeh, C. I. (2007) Poverty Profiles and Determinants of Expenditures of Rural Women Households in Abia State, Nigeria. The Nigerian Journal of Development Studies, 6(1): 187 2004.

Imo State Fadama Development (2000). Implementation Progress Report to the World Bank Supervision Mission to Imo State, Feb 5 - 7 Imo SFD pp. 1 -6 .

Khan, M. H. (2000) Rural Poverty in Developing Countries. Finance and Development, December, Washington IMF.

National Agricultural Extension and Research Liaison Services (NAERLS) (1995). South East Zone Extension Briefs. Ahmadu Bello University Zaria 1(7).

Nnanyelugo, D. O. (1980). The Nutritional Status of Children in Nigeria: A Comprehensive Treatise. CSS Book Ltd. Lagos.

Nwachukwu, I. N. and C. I. Ezeh (2007) Impact of Selected Rural Development Programme on Poverty Alleviation in Ikwuano LGA, Abia State, Nigeria. AJFAND Online, 7(5): $1-17$.
Obasi, P. C. (1991). Resource Use Efficiency in Food Crop Production: A Case of the Owerri Agricultural zone of Imo State. MSc. Thesis University of Ibadan, Ibadan, Nigeria.

Okorji, E. C. (1999) Dimensions of Rural Poverty and Food Self-sufficiency Gap in Nigeria". In: Fabiyi, Y. L. and E. O. Idowu (eds.) Poverty Alleviation and Food Security in Nigeria. Nigerian Association of Agricultural Economists (NAAE): p. $52-58$.

Olusanya, E. O. (1980) Food and Consumption Studies in Two Selected Rural Areas of Nigeria: Implication and Nutrition Policy". Nutri. Sc., 1.: 4-46

Onyenucheya, F. and O. O. Ukoha (2007) Loan Repayment and Credit Worthiness of Farmers under the Nigerian Agricultural Cooperative and Rural Development Bank (NACRDB). Agricultural Journal, 2(2): $265-270$.

Ryan, S. A.; R. J. Winstra; H. E. Kauffman; J. A. Jadcobs and T. E. Gleason (1986) The Soyabean Solution: Meeting World Food Needs. Urbana Champaign, College of Agriculture, University of Illinois. P. 13

World Bank (1996) Nigeria: Poverty in the Midst of Plenty: The Challenge of Growth with inclusion in the World Bank Poverty Assessment. May 1996 No 14733 UN. 